\title{
Osteonecrosis of the jaws produced by sunitinib: a systematic review
}

\author{
Carmen Vallina ${ }^{1}$, Lucía Ramírez ${ }^{2}$, Jesús Torres ${ }^{3}$, Elisabeth Casañas ${ }^{4}$, Gonzalo Hernández ${ }^{5}$, Rosa-María \\ López-Pintor ${ }^{6}$
}

${ }^{1}$ DDS, Oral Medicine Postgraduate. Department of Dental Clinical Specialties. School of Dentistry. Complutense University, Madrid, Spain

${ }^{2}$ DDS, PhD Student, Oral Medicine Postgraduate. Department of Dental Clinical Specialties. School of Dentistry. Complutense University, Madrid, Spain

${ }^{3}$ DDS, PhD, Professor. Department of Dental Clinical Specialties. School of Dentistry. Complutense University, Madrid, Spain

${ }^{4}$ DDS, PhD, Researcher, Oral Medicine Postgraduate. Department of Dental Clinical Specialties. School of Dentistry. Complutense University, Madrid, Spain

${ }^{5}$ MD, DDS, PhD, Professor, Director Specialty in Oral Medicine. Department of Dental Clinical Specialties. School of Dentistry. Complutense University, Madrid, Spain

${ }^{6} \mathrm{DDS}, \mathrm{PhD}$, Associate Professor, Co-director Speciality in Oral Medicine. Department of Dental Clinical Specialties. School of Dentistry. Complutense University, Madrid, Spain

Correspondence:

Departamento de Especialidades Clínicas Odontológicas

Facultad de Odontología

Universidad Complutense de Madrid

Plaza Ramón y Cajal $S / N$

28040-Madrid

Spain

rmlopezp@ucm.es

Vallina C, Ramírez L, Torres J, Casañas E, Hernández G, López-Pintor RM. Osteonecrosis of the jaws produced by sunitinib: a systematic review. Med Oral Patol Oral Cir Bucal. 2019 May 1;24 (3):e326-38. http://www.medicinaoral.com/medoralfree01/v24i3/medoralv24i3p326.pdf

Received: 22/08/2018 Accepted: $10 / 12 / 2018$

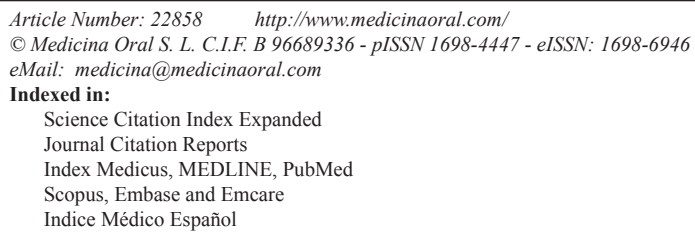

\begin{abstract}
Background: Tyrosine kinase receptor family is involved in tumor growth, pathological angiogenesis and the progression (metastasis) of cancer. Sunitinib (Sutent ${ }^{\circledR}$ ) inhibits members of the tyrosine kinase receptor family affecting the induction of angiogenesis and tumor progression. It is not clear if sunitinib increases the risk of osteonecrosis of the jaws (ONJ). The aim of this study was to carry out a systematic review about ONJ related to sunitinib, describing existing cases and possible associated risk factors.

Material and Methods: The PubMed/MEDLINE and Cochrane Library databases were searched without date restriction up to September 2018. We included prospective and retrospective observational studies, cross-sectional studies, clinical cases and series of cases, involving only human subjects. The methodological quality of the studies was assessed using The Joanna Briggs Institute (JBI) and Newcastle-Ottawa tools.

Results: A total of 13 studies fulfilled our inclusion criteria of which 7 were clinical cases, 5 case series and a retrospective study. All the articles were published between 2009 and 2018. Of the 102 patients treated with sunitinib analyzed in this study, 58 developed ONJ, being or having been treated with sunitinib and bisphosphonates or exclusively with sunitinib.
\end{abstract}


Conclusions: In this systematic review, we found an increase of ONJ in patients who are medicated with other drugs different than bisphosphonates and denosumab. It is necessary that dentists, oral and maxillofacial surgeons as well as oncologists know the risk of ONJ that these antiresorptive drugs could have. There is a need to continue researching in this field with the aim of an increasing knowledge in this area and creating an adequate protocol of action for this population.

Key words: Medication-related osteonecrosis of the jaws, osteonecrosis of the jaws, sunitinib, systematic review.

\section{Introduction}

Medication-related osteonecrosis of the jaws (MRONJ) is a chronic osteomyelitis-type of slow and torpid evolution with the presence of one or several bone exposures, without healing for at least 8 weeks, described with relative frequency in patients who have suffered cancer or bone related diseases and have been treated with antiresorptive drugs. According to the current consensus, the clinic and the medical history are enough to establish the diagnosis. There are different risk factors associated with MRONJ. The American Association of Oral and Maxillofacial Surgeons (AAOMS) considers those related to medication (potency of the drug, duration of treatment), local factors (extractions, implants, periodontal surgery, tori, and trauma), demographic and systemic factors (advanced age, tobacco and concomitant treatment with corticosteroids and chemotherapeutic agents) and genetic factors (1).

The first cases of MRONJ that showed an association between bisphosphonates and ONJ date from 2003 (2). So far, ONJ associated with bisphosphonates has been studied in depth. However, the relationship between ONJ with antiresorptive drugs such as RANKL inhibitors (denosumab) and other oncological drugs such as bevacizumab and sunitinib is being studied at the present time (1).

Tyrosine kinase receptor family is involved in tumor growth, pathological angiogenesis and the progres-

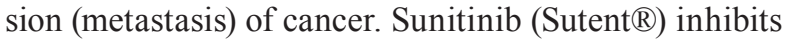
members of the tyrosine kinase receptor family including platelet-derived growth receptors (PDGFRD and PDGFRE), vascular endothelial growth factors (VEGFR1, VEGFR2 and VEGFR3), stem cell factor receptor (KIT), tyrosine kinase type 3 (FLT3), the colony stimulating factor $1 \mathrm{R}$ (CSF-1R) and the neurotrophic factor receptor derived from the glial cell line (RET) $(3,4)$. By inhibition of this signaling pathway, sunitinib affects the induction of angiogenesis and tumor progression. It was introduced for the first time in the US in 2006 in order to treat renal cell carcinoma, as well as gastrointestinal, pulmonary, thyroid and hematological tumors $(3,5)$. Different studies have demonstrated its efficacy, showing remarkable delays in the progression of the disease and a significant benefit in overall survival (6). The first cases of ONJ related to sunitinib date from 2010, when 27 cases of ONJ were described in 100,000 patients treated with this drug, in the period between January and November 2010 in the United Kingdom (7). However, it is not clear if sunitinib is a causal agent of MRONJ. The cases described are not so numerous as in the case of bisphosphonates. It is believed that sunitinib causes ONJ because it slow down bone remodeling and antagonizes the process of mucosal healing by inhibiting surrounding fibroblasts and endothelial cells, causing bone exposure after dental treatment (8). Other authors suggest that the reduction of angiogenesis caused by sunitinib may impair the host's defenses against infection, which increases the risk of necrosis (9).

The objective of this work is to carry out a systematic review about ONJ produced by sunitinib, by describing the existing cases and the possible associated risk factors.

\section{Material and Methods}

This systematic review was prepared in accordance with the "Preferred Reporting Items for Systematic Review and Meta-Analysis Protocols" (PRISMA-P, 2015) (10). The addressed focused PECOS (population, exposure, comparison, and outcome) question was as follows: Do patients who have received or are receiving sunitinib as treatment for oncological processes, either exclusively or in combination with other drugs associated to ONJ, suffer from MRONJ?

As a population we consider those patients who suffer from oncological pathologies and receive sunitinib. The exposure refers to the fact these patients have been or are being treated with sunitinib. The risk of ONJ will be compared, whenever possible, between those who have received exclusively sunitinib and patients who have received sunitinib in combination with bisphosphonates or other anti-angiogenic drugs. It will always be determined as a result that the patient has developed ONJ, defined according to current criteria (11).

-Eligibility Criteria

We have included 1) prospective and retrospective observational studies, cross-sectional studies, clinical cases and series of cases, 2) involving only human subjects, 3) without date restriction, 4) with full text availability, 5) written in English and 6) published in scientific journals.

The exclusion criteria were 1) articles about ONJ in which patients were not receiving or had not received 
treatment with sunitinib, 2) systematic and bibliographic reviews, letters to the editor and experimental studies on animals, 3) only the summary was available and 4) written in a language other than English.

-Information sources and search strategy

An exhaustive search of the literature was carried out, without restriction of date until September 24, 2018 in PubMed/MEDLINE and the Cochrane Library electronic databases. The keywords used were "sunitinib" AND "osteonecrosis" OR "osteonecrosis of the jaw" OR "osteonecrosis of the jaws". Two independent researchers (CV, LR) compared search results to ensure completeness. Duplicates were removed and the full title and abstract of each remaining article were screened individually (Fig. 1). Any differences in the selection of eligible studies were resolved by discussion with a third reviewer (RMLP).

-Data collection.

Two independent reviewers (CV, LR) extracted data from selected articles that met inclusion criteria. Any disagreement was resolved with the help of a third reviewer (RMLP). The following information was collected: 1) General characteristics of the selected studies: title of article, first author, year, type of study, tittle of the journal in which it was published, center and country where it was carried out. 2) Characteristics of the patients studied: number, sex, age, and illness for which they were taking sunitinib. 3) Data regarding sunitinib: dose, duration of treatment and other concomitant treatments. 4) Data related to ONJ: definition, location, stage, triggering factors and treatment for ONJ (Table 1, 1 continue, 1 continue- 1,1 continue-2).

-Risk of bias in individual studies

Two independent reviewers (CV, LR) evaluated the methodological quality of the eligible studies. If there were no agreement on one paper, it was evaluated by a third reviewer (RMLP). For this evaluation, the critical tools of The Joanna Briggs Institute (JBI) (12) for case series and clinical cases and the Newcastle-Ottawa's scale (13) for cohort studies were used. We use the JBI clitical appraisal tools for case reports and case series, according to the type of article. The bias is evaluated through a checklist of 8 questions for case report and 10 questions for case series. Each question is specified in Table 2 and Table 3 concerning risk of bias. Finally, an overall appraisal is made of each article determining if the risk of bias is low (included), high (excluded), or uncertain (more information needs to be sought). We considered a low risk of bias if the answers "yes" were $\geq 50 \%$, high risk of bias if the answers "no" were $\geq 50 \%$, and uncertain risk of bias if the "unclear" answers were $\geq 50 \%$ (12).

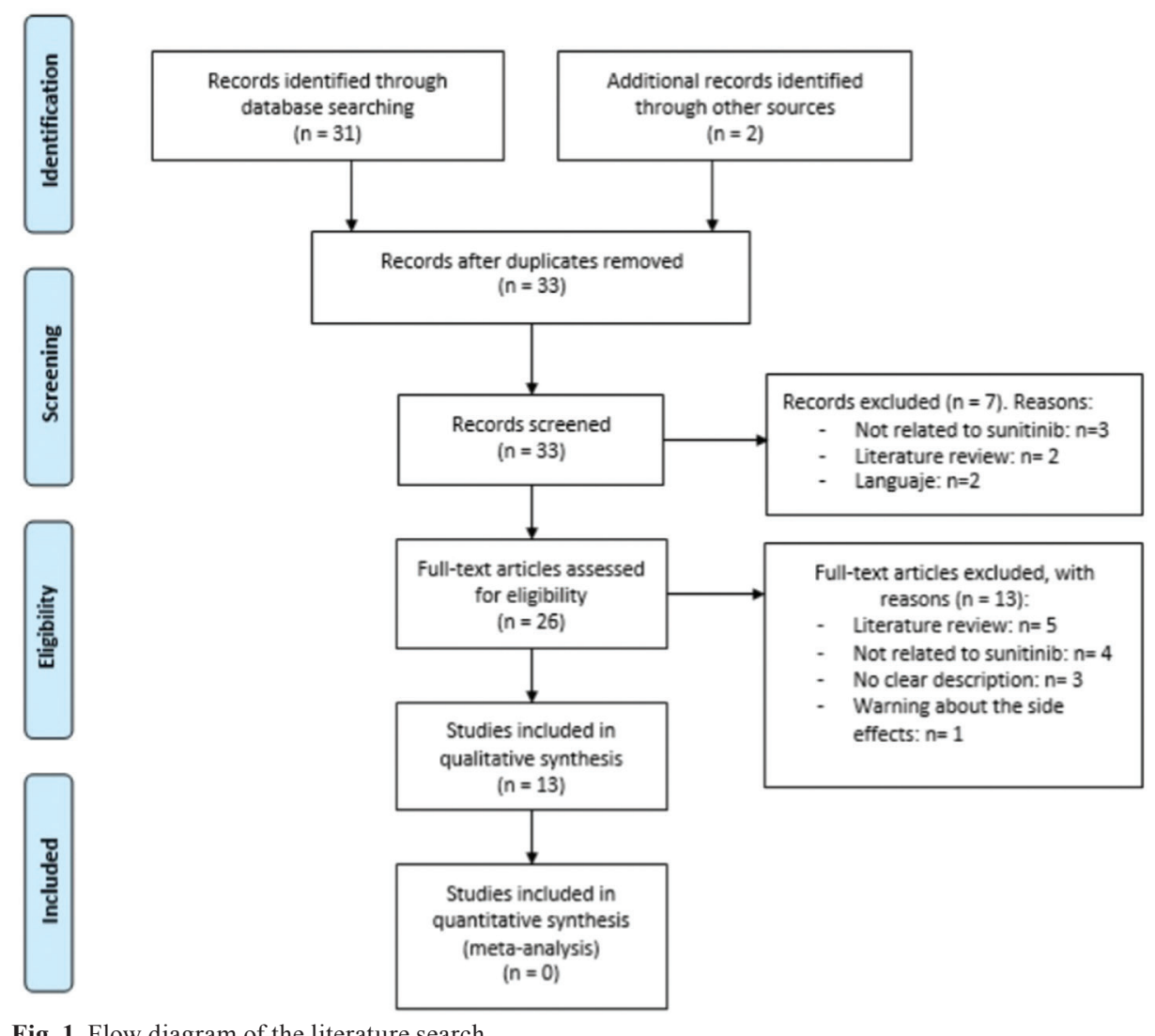

Fig. 1. Flow diagram of the literature search. 
Table 1. Description of identified studies.

\begin{tabular}{|c|c|c|c|c|c|c|}
\hline $\begin{array}{l}\text { Author, year, center } \\
\text { and country. }\end{array}$ & $\begin{array}{l}\text { Type of } \\
\text { study }\end{array}$ & $\begin{array}{l}\text { Number of } \\
\text { patients }\end{array}$ & $\begin{array}{l}\text { Sex, age } \\
\text { (average } \\
\pm \mathrm{SD})\end{array}$ & $\begin{array}{l}\text { Disease for } \\
\text { which sunitinib } \\
\text { is administered }\end{array}$ & Sunitinib + other drugs & ONJ \\
\hline $\begin{array}{l}\text { Mahedi Mohamed } \\
\text { HA et al. } \\
2018 . \\
\text { Department of Oral \& } \\
\text { Maxillofacial Surgery. } \\
\text { Copenhagen, } \\
\text { Denmark }^{20} \text {. }\end{array}$ & Case series & $\mathrm{n}=1$ & $\begin{array}{l}\text { M } \\
\text { Age: } 70\end{array}$ & $\mathrm{RCC}$ & $\begin{array}{l}\text { Dose: } 50 \mathrm{mg} / \mathrm{day} \\
\text { Duration: } 9 \text { months } \\
\text { Not combined with BFs }\end{array}$ & $\begin{array}{l}\text { Location: jaw } \\
\text { Time to onset: NA } \\
\text { Risk factors: extraction, diabetes } \\
\text { Stage: I } \\
\text { Treatment: NA } \\
\text { Resolution time: NA }\end{array}$ \\
\hline $\begin{array}{l}\text { Asheafi F et al. } \\
2017 . \\
\text { Department of Internal } \\
\text { Medicine, } \\
\text { Haematology Section, } \\
\text { Isfahan University of } \\
\text { Medical Sciences, } \\
\text { Isfahan, Iran }{ }^{14} \text {. }\end{array}$ & Case report & $\mathrm{n}=1$ & $\begin{array}{l}\text { M } \\
\text { Age: } 53\end{array}$ & $\begin{array}{l}\mathrm{RCC}+\text { Lung } \\
\text { metastasis }\end{array}$ & $\begin{array}{l}\text { Dose: } 50 \mathrm{mg} / \text { day } \\
\text { Duration: } 5 \text { months } \\
\text { Not combined with BFs } \\
\text { currently } \\
2 \text { cycles of zoledronic acid: } 4 \\
\text { mg intravenously, more than } 7 \\
\text { months before ONJ }\end{array}$ & 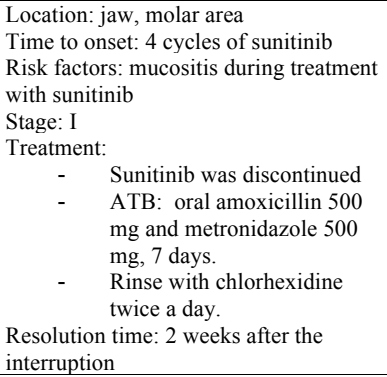 \\
\hline $\begin{array}{l}\text { Fusco V et al. } \\
2015 . \\
\text { Department of } \\
\text { Oncology and } \\
\text { Hematology. } \\
\text { Alessandria, Italy }{ }^{21} \text {. }\end{array}$ & Case series & $\mathrm{n}=44$ & $\begin{array}{l}\text { M: } n=35 \\
(82 \%) \\
F: n=9 \\
(18 \%) \\
\text { Age: } 63 \pm \\
20\end{array}$ & NA & $\begin{array}{l}\text { Dose: } 50 \mathrm{mg} / \text { day } \\
\text { Duration: } 1-24 \text { months } \\
\text { Combined with BFs }\end{array}$ & 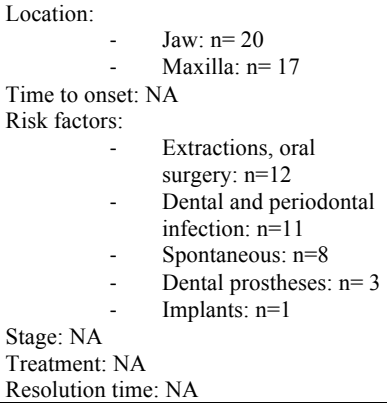 \\
\hline $\begin{array}{l}\text { Smidt-Hansen } \text { et al. } \\
2013 . \\
\text { Department of } \\
\text { Oncology, Aarhus } \\
\text { University Hospital, } \\
\text { Denmark }^{22} \text {. }\end{array}$ & Case series & $\mathrm{n}=43$ & $\begin{array}{l}\text { M: } \\
- \text { Cohort } \\
\text { A: } n=16 \\
- \\
\text { Cohort.B: } \\
n=11 \\
- \\
\text { Cohort.C: } \\
n=5 \\
\text { Age: : } \\
\text { Cohort A: } \\
63(47-76) \\
\text { Cohort B: } \\
58(42- \\
72) \\
\text { Cohort C: } \\
60(32- \\
73)\end{array}$ & $\begin{array}{l}\mathrm{RCC}+\text { Bone } \\
\text { metastasis }\end{array}$ & $\begin{array}{l}\text { Dose: } 50 \mathrm{mg} / \text { day } \\
\text { In cohort A, } 15 \text { patients } \\
\text { received sunitinib as } 1 \text { st line of } \\
\text { tx, } 2 \text { as } 2 \text { nd line of tx, and } 4 \text { as } \\
3 \text { rd line of tx. } 6 \text { cases of ONJ. } \\
\text { In cohort B, } 7 \text { patients received } \\
\text { sunitinib as } 1 \text { st line of tx, } 3 \text { as } \\
2 \text { nd line of tx, and } 5 \text { as } 3 \text { rd line } \\
\text { of tx. } \\
\text { In cohort C, } 3 \text { patients received } \\
\text { sunitinib as } 1 \text { st line of tx, } 2 \text { as } \\
2 \text { nd line of tx, and } 2 \text { as } 3 \text { rd line } \\
\text { of tx. } 1 \text { case of ONJ. }\end{array}$ & 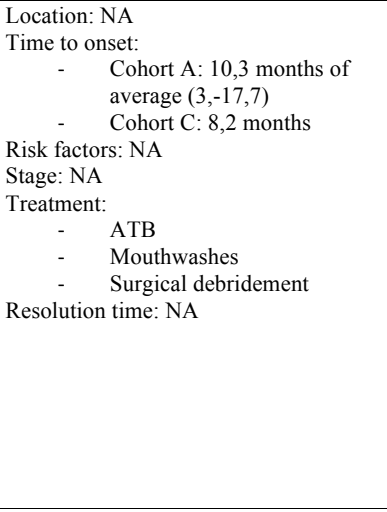 \\
\hline $\begin{array}{l}\text { Agrillo A et al. } \\
2012 . \\
\text { Department of } \\
\text { Maxillo-Facial } \\
\text { Surgery, "Sapienza" } \\
\text { University, Rome, } \\
\text { Italy". }\end{array}$ & Case report & $\mathrm{n}=2$ & $\begin{array}{l}\text { Patient 1: } \\
\text { M } \\
\text { Age: } 56 \\
\text { Patient 2: } \\
\text { M } \\
\text { Age: } 67\end{array}$ & $\begin{array}{l}\text { Patient 1: RCC } \\
\text { Patient 2: RCC + } \\
\text { bone metastasis }\end{array}$ & $\begin{array}{l}\text { Patient } 1: \\
\text { Dose: } 50 \mathrm{mg} / \text { day; Then } 37,5 \\
\text { mg. } \\
\text { Duration: } 24 \text { months } \\
\text { Combined with BFs } \\
\text { (zolendronic acid, } 4 \mathrm{mg} / \text { month) } \\
\\
\text { Patient } 2: \\
\text { Dose: } 50 \mathrm{mg} / \text { day } \\
\text { Duration: } 1 \text { cycle }+7 \text { cycles } \\
\text { combined with temsirolimus. }\end{array}$ & 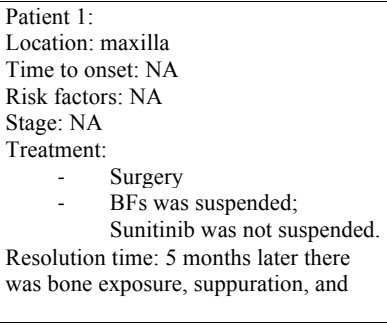 \\
\hline
\end{tabular}


Table 1 continue. Description of identified studies.

\begin{tabular}{|c|c|c|c|c|c|c|}
\hline & & & & & $\begin{array}{l}\text { Combined with chemotherapy } \\
\text { (methotrexate, doxorubicin and } \\
\text { Adriamycin, } 6 \text { cycles of } \\
\text { gemcitabine and Vinorelbine, } \\
\text { Roferon-A and fluorouracil). } \\
\text { Combined with BFs: } \\
\text { zolendroic acid } 13 \text { months, } \\
\text { temsirolimus } 7 \text { cycles. }\end{array}$ & $\begin{array}{l}\text { oroantral communication. He dies from } \\
\text { cancer. } \\
\text { Patient 2: } \\
\text { Location: jaw; submandibular area } \\
\text { (cutaneous fistula). } \\
\text { Time to onset: NA } \\
\text { Risk factors: NA } \\
\text { Stage: NA } \\
\text { Treatment: } \\
\text { - ATB: Penicillin. } \\
\text { - Antimicrobial rinses. } \\
\quad \text { - Rigid titanium plate } \\
\quad \text { (pathological mandibular } \\
\text { fracture) } \\
\text { Resolution time: NA. He dies from } \\
\text { cancer. }\end{array}$ \\
\hline $\begin{array}{l}\text { Fleissig Y et al. } \\
2012 . \\
\text { Department of Oral } \\
\text { and Maxillofacial } \\
\text { Surgery, Hadassah- } \\
\text { Hebrew University } \\
\text { Medical Center, } \\
\text { Jerusalem, Israel }{ }^{7} \text {. }\end{array}$ & Case report & $\mathrm{n}=1$ & $\begin{array}{l}\text { F } \\
\text { Age: } 58\end{array}$ & RCC & $\begin{array}{l}\text { Dose: } 50 \mathrm{mg} / \text { day } \\
\text { Duration: } 24 \text { months } \\
\text { Not combined with BFs }\end{array}$ & 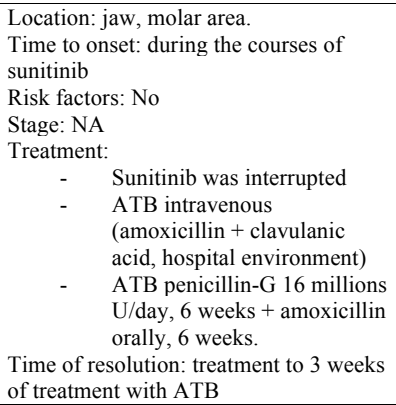 \\
\hline $\begin{array}{l}\text { Balmor GR } \text { et al. } \\
2012 . \\
\text { Departments of } \\
\text { Medicine B, Oral and } \\
\text { Maxillofacial Surgery, } \\
\text { and Oncology, Sheba } \\
\text { Medical Center, Tel } \\
\text { Hashomer, Israel }^{16} \text {. }\end{array}$ & Case report & $\mathrm{n}=1$ & $\begin{array}{l}\text { M } \\
\text { Age: } 63\end{array}$ & $\begin{array}{l}\mathrm{RCC}+\text { Lung and } \\
\text { bone metastasis }\end{array}$ & $\begin{array}{l}\text { Dose: } 50 \mathrm{mg} / \text { day } \\
\text { Duration: } 36 \text { months } \\
\text { Combined with BFs: monthly } \\
\text { pamidronate }\end{array}$ & $\begin{array}{l}\text { Location: jaw, maxilla } \\
\text { Time to onset: NA } \\
\text { Risk factors: } \\
-\quad \text { Extractions } \\
-\quad \text { Breast surgery with } \\
\\
\text { submucosal resection } \\
\text { Stage: NA } \\
\text { Treatment: } \\
-\quad \text { Sunitinib and pamidronate } \\
\quad \quad \text { was interrupted } \\
-\quad \text { Antiseptic rinses } \\
-\quad \text { Surgical debridement } \\
\text { Time of resolution: NA }\end{array}$ \\
\hline $\begin{array}{l}\text { Nicolatou-Galitis O } \\
\text { et al. } \\
2012 \text {. } \\
\text { Clinic of Hospital } \\
\text { Dentistry, Dental } \\
\text { Oncology Unit,School } \\
\text { of Dentistry, } \\
\text { University of Athens, } \\
\text { Greece'. }\end{array}$ & Case series & $\mathrm{n}=2$ & $\begin{array}{l}\text { Patient 1: } \\
\text { F } \\
\text { Age: } 19 \\
\text { Patient 2: } \\
\text { F } \\
\text { Age: } 64\end{array}$ & $\begin{array}{l}\text { Patient 1: RCC } \\
\text { Patient 2: RCC + } \\
\text { Lung metastasis }\end{array}$ & $\begin{array}{ll}\text { Complications by sunitinib: } \\
\text { Patient 1: } \\
-\quad & \text { Oral pain } \\
- & \text { Halitosis } \\
- & \text { Persistent gingival } \\
& \text { bleeding ( }>5 \text { days) } \\
\text { Patient 2: } & \text { Pain > } 1 \text { month } \\
\end{array}$ & 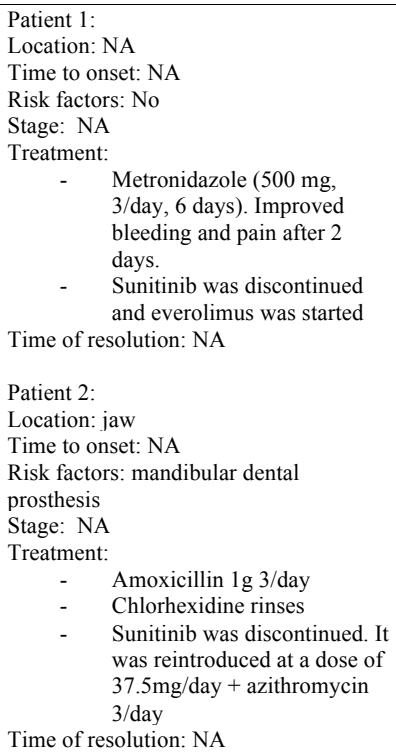 \\
\hline
\end{tabular}


Table 1 continue-1. Description of identified studies.

\begin{tabular}{|c|c|c|c|c|c|c|}
\hline $\begin{array}{l}\text { Hoefert S et al. } \\
2010 . \\
\text { Department of oral } \\
\text { and maxilofacial } \\
\text { surgery, regional } \\
\text { plastic surgery } \\
\text { Ruhr Hospital, } \\
\text { Germany }{ }^{4} \text {. }\end{array}$ & Case series & $\mathrm{n}=3$ & $\begin{array}{l}\text { Patient 1: } \\
\text { NA } \\
\text { Age: } 55 \\
\text { Patient 2: } \\
\text { NA } \\
\text { Age: } 56 \\
\text { Patient 3: } \\
\text { M } \\
\text { Age: } 62\end{array}$ & $\begin{array}{l}\text { Patient 1: RCC. } \\
\text { Patient 2: RCC. } \\
\text { Patient 3: RCC + } \\
\text { Bone metastasis }\end{array}$ & $\begin{array}{l}\text { Dose: } 50 \mathrm{mg} / \text { day } \\
\text { Patients } 2 \text { and 3: Sunitinb + } \\
\text { BFs (zolendronate) }\end{array}$ & 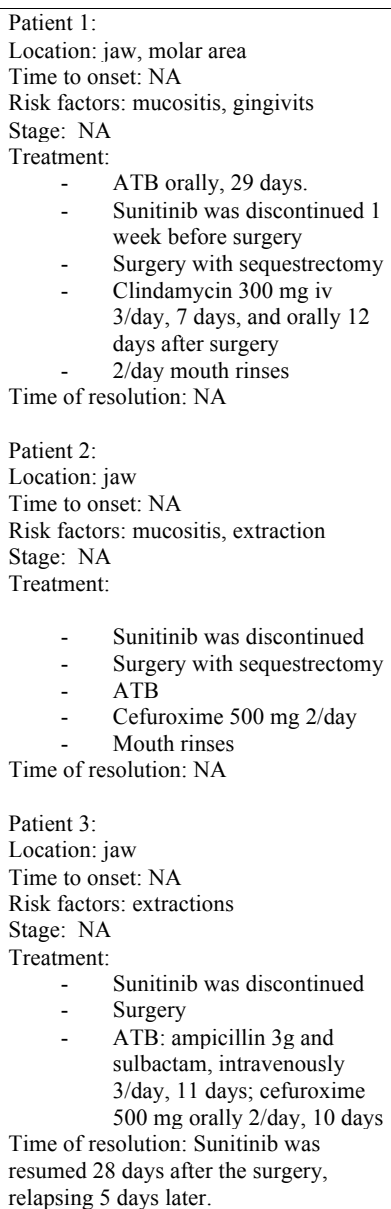 \\
\hline $\begin{array}{l}\text { Bozas G et al. } \\
2010 . \\
\text { Department of } \\
\text { Medical Oncology, } \\
\text { Castle Hill Hospital, } \\
\text { Cottingham, Hull and } \\
\text { East Yorkshire } \\
\text { Hospitals NHS Trust, } \\
\text { United Kingdom }{ }^{17} \text {. }\end{array}$ & Case report & $\mathrm{n}=1$ & $\begin{array}{l}\text { M } \\
\text { Age: } 51\end{array}$ & $\begin{array}{l}\text { RCC + Bone and } \\
\text { hepatic metástasis }\end{array}$ & $\begin{array}{l}\text { Dose: } 50 \mathrm{mg} / \text { day } \\
\text { Duration: } 23 \text { months } \\
\text { Combined with BFs } \\
\text { (zoledronic acid) }\end{array}$ & $\begin{array}{l}\text { Location: jaw, molar area } \\
\text { Time to onset: } 4 \text { days after the first } \\
\text { administration of zoledronic acid } \\
\text { Risk factors: no } \\
\text { Stage: NA } \\
\text { Treatment: } \\
\text { - Zoledronic acid was } \\
\quad \text { suspended } \\
\text { - } \quad \text { Sunitinib is continued } \\
\text { - } \quad \text { Oral hygiene, not smoking } \\
\text { Hyperbaric oxygen: Marx } \\
\text { protocol 30/10 } \\
\text { Time of resolution: } \\
\text { - Improvement } 6 \text { weeks after } \\
\text { the start of the treatment } \\
\text { Complete healing of the } \\
\text { mucosa } 1 \text { month later } \\
\text { - There was no recurrence of } \\
\text { ONJ during } 23 \text { months. } \\
\end{array}$ \\
\hline $\begin{array}{l}\text { Koch FP } \text { et al. } \\
2011 . \\
\text { Oral and Maxillofacial } \\
\text { Surgery, University } \\
\text { Medical Centre of the } \\
\text { Johannes Gutenberg } \\
\text { University, Mund-, } \\
\text { Kiefer-und } \\
\text { Gesichtschirurgie, } \\
\text { Mainz, Germany }{ }^{17} \text {. }\end{array}$ & Case report & $\mathrm{n}=1$ & $\begin{array}{l}\text { M } \\
\text { Age: } 59\end{array}$ & $\begin{array}{l}\text { RCC }+ \text { Soft tissue } \\
\text { metastasis }\end{array}$ & $\begin{array}{l}\text { Dose: } 50 \mathrm{mg} / \text { day } \\
\text { Duration: } 1 \mathrm{month} \text {. } \\
\text { Maintenance: } 37.5 \mathrm{mg} / \text { day } \\
\text { Not combined with BFs }\end{array}$ & $\begin{array}{l}\text { Location: jaw, molar area } \\
\text { Time to onset: NA } \\
\text { Risk factors: extraction } \\
\text { Stage: NA } \\
\text { Treatment: surgery } \\
\text { Time of resolution: NA. Resolution }\end{array}$ \\
\hline
\end{tabular}


Table 1 continue-2. Description of identified studies.

\begin{tabular}{|c|c|c|c|c|c|c|}
\hline $\begin{array}{l}\text { Christodoulou C et } \\
\text { al. } \\
2009 \text {. } \\
\text { Oncology Department, } \\
\text { Metropolitan Hospital, } \\
\text { Institute of Biomedical } \\
\text { Sciences (AIBS), } \\
\text { Athens, Greeces }\end{array}$ & Retrospective. & $\mathrm{n}=1$ & $\begin{array}{l}\text { M } \\
\text { Age: } 48\end{array}$ & $\begin{array}{l}\text { RCC + Lung and } \\
\text { bone metastasis }\end{array}$ & $\begin{array}{l}\text { Dose: } 50 \mathrm{mg} / \mathrm{day} \\
\text { Combined with BFs } \\
\text { (zoledronic acid, 4mg/4week) }\end{array}$ & $\begin{array}{l}\text { Location: jaw } \\
\text { Time to onset: } 28.5 \text { months } \\
\text { Risk factors: NA } \\
\text { Stage: NA } \\
\text { Treatment: } \\
\text { Tratamiento: } \\
\quad \text { - Zolendronate was suspended } \\
\text { - Sunitinib was continued } \\
\text { - ATB } \\
\text { Time of resolution: NA. Significant } \\
\text { improvement }\end{array}$ \\
\hline $\begin{array}{l}\text { Brunello A et al. } \\
2009 . \\
\text { Istituto Oncologico } \\
\text { Veneto, IOV-Padova, } \\
\text { Italy }^{19} \text {. }\end{array}$ & Case report & $\mathrm{n}=1$ & $\begin{array}{l}\text { M } \\
\text { Age: } 59\end{array}$ & $\begin{array}{l}\text { RCC + Lung } \\
\text { metastasis }\end{array}$ & $\begin{array}{l}\text { Dose: } 37.5 \mathrm{mg} / \text { day } \\
\text { Previously: zoledronic acid, } \\
\text { gemcitabine, } 5 \text {-fluorouracil }\end{array}$ & $\begin{array}{l}\text { Location: jaw } \\
\text { Time to onset: } 3 \text { months after sunitinib } \\
\text { Risk factors: no. } \\
\text { Stage: NA } \\
\text { Treatment: } \\
-\quad \text { Sunitinib was discontinued } \\
\text { - } \quad \text { ATB: Amoxicillin-clavulanic } \\
\text { 1g, orally, } 7 \text { days. } \\
\text { Metronidazole } 500 \mathrm{mg}, 7 \\
\quad \text { days. } \\
\text { Sunitinib resumed, } 3 \text { more } \\
\text { cycles } \rightarrow \text { relapse. Treatment } \\
\text { again. } \\
\text { Time of resolution: remains of ONM } \\
\text { during } 5 \text { months; improvement. }\end{array}$ \\
\hline
\end{tabular}

F, female; M, male; MA, mean age; SD: standard desviation; RCC, renal cell cancer; BFs, bisphosphonates; TKI, tyrosine kinase inhibitor; Cohort A, treatment of sunitinib and zolendronic acid to prevent skeletal complications without prior dental examination; Cohort B, treatment of sunitinib and zolendronic acid to reduce hypercalcemia without prior dental examination; Cohort $\mathrm{C}$, treatment of sunitinib and zolendronic acid with previous dental examination; tx, treatment; ATB, antibiotic; NA, not available.

Table 2. Risk of bias for case reports.

\begin{tabular}{|c|c|c|c|c|c|c|c|}
\hline & $\begin{array}{l}\text { Ashrafi et al. } \\
\quad 2017\end{array}$ & $\begin{array}{l}\text { Agrillo et al. } \\
2012\end{array}$ & $\begin{array}{l}\text { Fleissig et } \\
\text { al. } 2012\end{array}$ & $\begin{array}{l}\text { Balmor et } \\
\text { al. } 2012\end{array}$ & $\begin{array}{l}\text { Koch et al. } \\
\quad 2012\end{array}$ & $\begin{array}{l}\text { Bozas et al. } \\
\quad 2010\end{array}$ & $\begin{array}{l}\text { Brunello et } \\
\text { al. } 2009\end{array}$ \\
\hline $\begin{array}{l}\text { Were patient's demographic } \\
\text { characteristics clearly } \\
\text { described? }\end{array}$ & Yes & Yes & Yes & Yes & Yes & Yes & Yes \\
\hline $\begin{array}{l}\text { Was the patient's history } \\
\text { clearly described and } \\
\text { presented as a timeline? }\end{array}$ & Yes & Yes & Yes & Yes & Yes & Yes & Yes \\
\hline $\begin{array}{l}\text { Was the current clinical } \\
\text { condition of the patient on } \\
\text { presentation clearly } \\
\text { described? }\end{array}$ & Yes & Yes & Yes & Yes & Yes & Yes & Yes \\
\hline $\begin{array}{l}\text { Were diagnostic tests or } \\
\text { assessment methods and the } \\
\text { results clearly described? }\end{array}$ & Yes & Yes & Yes & Yes & Yes & Yes & Yes \\
\hline $\begin{array}{l}\text { Was the intervention(s) or } \\
\text { treatment procedure(s) clearly } \\
\text { described? }\end{array}$ & Yes & Yes & Yes & Yes & No & Yes & Yes \\
\hline $\begin{array}{l}\text { Was the post-intervention } \\
\text { clinical condition clearly } \\
\text { described? }\end{array}$ & Yes & No & Yes & No & No & Yes & Yes \\
\hline $\begin{array}{l}\text { Were adverse events (harms) } \\
\text { or unanticipated events } \\
\text { identified and described? }\end{array}$ & Yes & Yes & Yes & Yes & Yes & Yes & Yes \\
\hline $\begin{array}{l}\text { Does the case report provide } \\
\text { takeaway lessons? }\end{array}$ & Yes & Yes & Yes & Yes & Yes & Yes & Yes \\
\hline Overall appraisal & Included & Included & Included & Included & Included & Included & Included \\
\hline
\end{tabular}


Table 3. Risk of bias for case series.

\begin{tabular}{|c|c|c|c|c|c|}
\hline & $\begin{array}{c}\text { Mahedi } \\
\text { Mohamed et } \\
\text { al. } 2018\end{array}$ & $\begin{array}{l}\text { Fusco et } \\
\text { al. } 2015\end{array}$ & $\begin{array}{l}\text { Smidt-Hansen } \\
\text { et al. } 2013\end{array}$ & $\begin{array}{l}\text { Nicolatou-Galitis } \\
\quad \text { et al. } 2012\end{array}$ & $\begin{array}{l}\text { Hoefert et al. } \\
\quad 2010\end{array}$ \\
\hline $\begin{array}{l}\text { Were there clear criteria for } \\
\text { inclusion in the case series? }\end{array}$ & Yes & Yes & Yes & No & No \\
\hline $\begin{array}{l}\text { Was the condition measured in } \\
\text { a standard, reliable way for all } \\
\text { participants included in the case } \\
\text { series? }\end{array}$ & Yes & Yes & Yes & Yes & Yes \\
\hline $\begin{array}{l}\text { Were valid methods used for } \\
\text { identification of the condition for } \\
\text { all participants included in the } \\
\text { case series? }\end{array}$ & Yes & Yes & Yes & Yes & Yes \\
\hline $\begin{array}{l}\text { Did the case series have } \\
\text { consecutive inclusion of } \\
\text { participants? }\end{array}$ & Yes & Yes & Unclear & Unclear & Unclear \\
\hline $\begin{array}{l}\text { Did the case series have complete } \\
\text { inclusion of participants? }\end{array}$ & Unclear & Unclear & Unclear & Unclear & Unclear \\
\hline $\begin{array}{l}\text { Was there clear reporting of the } \\
\text { demographics of the participants } \\
\text { in the study? }\end{array}$ & Yes & Yes & Yes & Yes & Yes \\
\hline $\begin{array}{l}\text { Was there clear reporting of } \\
\text { clinical information of the } \\
\text { participants? }\end{array}$ & Yes & Yes & Yes & Yes & Yes \\
\hline $\begin{array}{l}\text { Were the outcomes or follow up } \\
\text { results of cases clearly reported? }\end{array}$ & Yes & Yes & Yes & Yes & Yes \\
\hline $\begin{array}{l}\text { Was there clear reporting of the } \\
\text { presenting site(s)/clinic(s) } \\
\text { demographic information? }\end{array}$ & Yes & Yes & Yes & Yes & Yes \\
\hline $\begin{array}{l}\text { Was statistical analysis } \\
\text { appropriate? }\end{array}$ & Unclear & Yes & Yes & Unclear & Unclear \\
\hline Overall appraisal & Included & Included & Included & Included & Included \\
\hline
\end{tabular}

We used Newcastle-Ottawa's scale to assess the risk of bias of the included retrospective study. The bias is evaluated through a questionnaire divided into $3 \mathrm{sec}-$ tions. The first one is "Selection" and it has 4 items. The second section is called "Comparability" and it has only 2 items about the comparability of cohorts on the design or analysis. The last section is "Outcomes" and it has 3 items about the assessment of outcome and follow-up. Each question is specified in Table 4. We considered a low risk of bias if the study had $\geq 5$ of the stars (13). This Newcastle-Ottawa's scale is shown in Table 4.

-Risk of bias across studies

Graphs were made to evaluate the risk of bias of all the studies, grouping them according to the type of study. In this way, the risk of bias of the included articles was evaluated jointly, paying attention to the different questions posed by the JBI (Figs 2,3). No graph was shown for cohort studies because it was only one study.

\section{Results}

-Study selection

The search strategy yielded 33 results, without duplicates. The two independent researchers $(\mathrm{CV}, \mathrm{LR})$ reviewed all the titles and abstracts of the 33 articles. Seven articles were excluded: 2 papers due to language (French, Hungarian), 3 articles for not being related to sunitinib and 2 for being bibliographic reviews. (Annex 1).

After reading the full text, another 13 articles were excluded: 5 for being bibliographic reviews, 4 for not treating sunitinib, 3 for not explicitly describing the medication that patients took (not being able to obtain the number of patients medicated with sunitinib), and one for being a warning about the side effects of bevacizumab and sunitinib (Annex 1). Finally, 13 papers were included in the systematic review (Fig. 1).

-Study characteristics

Of the total number of studies included in this systematic review, we found 7 case reports, 5 case series and a retrospective study. All the articles were published in the last decade, between the years 2009 and 2018. The studies have 
Table 4. Risk of bias for retrospective studies.

\begin{tabular}{|c|c|c|}
\hline & & $\begin{array}{c}\text { Christodoulou et al. } \\
2009\end{array}$ \\
\hline \multicolumn{3}{|c|}{ SELECTION } \\
\hline & Representativeness of the exposed cohort & $*$ \\
\hline$\square$ & Selection of the non-exposed cohort & \\
\hline$\square$ & Ascertainment of exposure & $*$ \\
\hline$\square$ & $\begin{array}{l}\text { Demonstration that outcome of interest was not present at start of } \\
\text { study }\end{array}$ & $*$ \\
\hline \multicolumn{3}{|c|}{ COMPARABILITY } \\
\hline & Study controls for bisphosphonates and antiangiogenic therapy & $*$ \\
\hline$\square$ & Study control for any additional factor (duration of exposure) & * \\
\hline \multicolumn{2}{|c|}{$\begin{array}{l}\text { Assessment of outcome } \\
\text { Was follow-up long enough for outcomes to occur? } \\
\text { Adequacy of follow up of cohorts }\end{array}$} & $*$ \\
\hline \multicolumn{2}{|c|}{ NEWCASTLE-OTTAWA SCORE } & 8 \\
\hline
\end{tabular}

\section{Risk of bias for case reports}

\section{Were patient's demographic characteristics clearly described? \\ 2.Was the patient's history clearly described and presented as a timeline? \\ 3.Was the current clinical condition of the patient on presentation clearly described? \\ 4.Were diagnostic tests or assessment methods and the results clearly described? \\ 5.Was the intervention(s) or treatment procedure(s) clearly described? \\ 6.Was the post-intervention dinical condition clearly described? \\ 7.Were adverse events (harms) or unanticipated events identified and described? \\ 8.Does the case report provide takeaway lessons?}

Low risk of bias Unclear risk of bias High risk of bias

$0 \%$

Fig. 2. Risk of bias across studies for case reports.

been carried out in different countries: Italy, United Kingdom, Denmark, Greece, Germany, Israel and Iran. They were published in journals of different medical specialties among which are oral medicine, oral and maxillofacial surgery, oncology, urology, pharmacology and rheumatology. All the studies included a total of 102 patients treated with sunitinib, of which 59 developed MRONJ. The characteristics of the patients studied and the data relative to sunitinib and ONJ are shown in Table 1.

-Risk of bias of the studies individually

Following the criteria provided by the JBI (12) and Newcastle-Ottawa (13) quality assessment scales, the risk of bias in the studies was assessed. As shown in Table 2, the case reports provided by Ashrafi et al. (14),

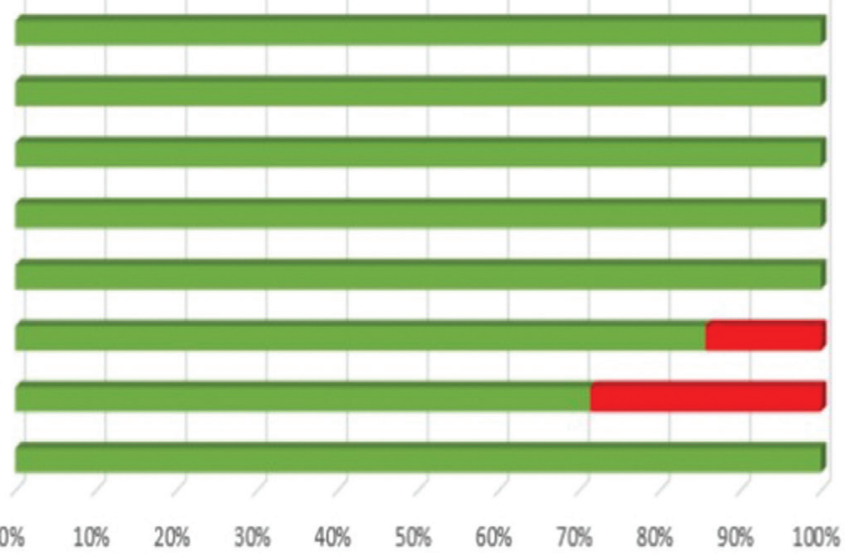

Agrillo et al. (15), Fleissig et al. (7), Balmor et al. (16), Bozas et al. (17), Koch et al. (18) y Brunello et al. (19) have a low risk of bias.

Table 3 shows the series of cases carried out by Mahedi Mohamed et al. (20), Fusco et al. (21), Smidt-Hansen et al. (22), Nicolatou-Galitis et al. (9) and Hoefert et al. (4) that presented a low risk of bias.

In the same way, following the criteria provided by the Newcastle-Ottawa's scale, the retrospective study completed by Christodoulou et al. (23) had a low risk of bias, obtaining a good score (8 stars) (Table 4).

-Results of individual studies (Table 1)

Of the 102 patients treated with sunitinib analyzed in this study, we can observe that 23 (22.54\%) were wom- 


\section{Risk of bias for case series}

\begin{abstract}
1. Were there dear criteria for inclusion in the case series?
2. Was the condition measured in a standard, reliable way for all participants induded in.

3. Were valid methods used for identification of the condition for all participants.

4. Did the case series have consecutive inclusion of participants?

5. Did the case series have complete indusion of participants?

6. Was there dear reporting of the demographis of the participants in the study?

7 . Was there dear reporting of clinical information of the participants?

8. Were the outcomes or follow up results of cases clearly reported?

9. Was there dear reporting of the presenting site(s)//linic(s) demographic information?
\end{abstract}

10. Was statistical aralysis appropriate?

\section{vLw risk of bias Unclear risk of bias High risk of bias}

Fig. 3. Risk of bias across studies for case series.

en and 77 (75.49\%) were men. Data from 2 (1.96\%) patients were not available (5). Regarding age, the average age was 57 years (minimum-maximum 19-70). Of these patients $58(56.86 \%)$ developed ONJ, of which 38 were males $(66 \%), 11$ females $(19 \%)$ and 9 cases did not specify sex (15\%). The average age of the patients with ONJ was 56 years.

Most patients received other medications that alter bone remodeling such as bisphosphonates or denosumab in addition to sunitinib. Forty-nine patients (84\%) with ONJ were under concomitant treatment with sunitinib and bisphosphonates, 5 patients $(9 \%)$ were treated exclusively with sunitinib, one patient $(2 \%)$ had previously received bisphosphonates although at present he was not treated with them, and another patient (2\%) was under combined treatment with sunitinib, bisphosphonates and chemotherapy.

Regarding the local risk factors, the authors highlight extractions and dentoalveolar surgery $(n=17,29 \%)$, followed by dental or periodontal infections $(n=11,19 \%)$, mucositis due to chemotherapy $(n=3,5 \%)$, use of removable dentures $(n=3,5 \%)$ or implant insertion $(n=1,2 \%)$. In 8 cases the ONJ was spontaneous (14\%) and in 15 cases $(26 \%)$ the associated risk factors were not specified.

Patients received sunitinib orally, and the duration of the treatment ranged from 1 to 36 months. Most of the patients with ONJ received sunitinib at a dose of $50 \mathrm{mg} /$ day (91\%), $4 \%$ at a dose of $37.5 \mathrm{mg} /$ day and $2 \%$ received first $50 \mathrm{mg} /$ day and were subsequently maintained at a dose of 37.5 $\mathrm{mg} /$ day. Doses of 2 patients were not available (3\%) (9).

Regarding ONJ location, 8 cases (13\%) did not specify

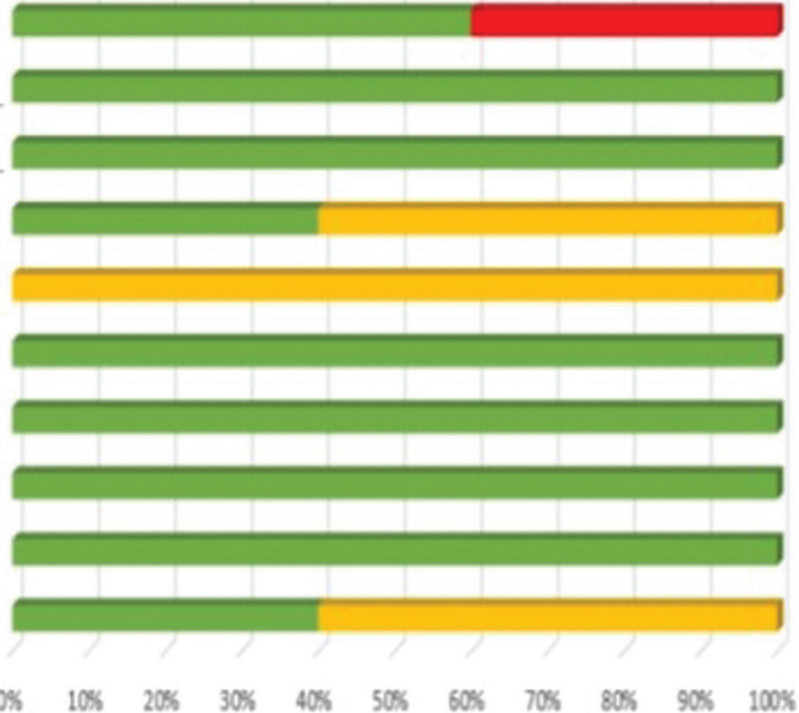

the location and in the remaining cases 34 occurred in the mandible (54\%) and 21 in the maxilla (33\%). Only in two cases was the stage specified at the time of diagnosis, being stage I $(14,20)$.

With regards to the treatment, $26 \%$ of the subjects with ONJ received antibiotic therapy, chlorhexidine mouthwashes were recommended in $18 \%$ of cases and surgery was performed in $16 \%$ of cases. The authors proceeded to suspend sunitinib in $18 \%$ of the cases, while the bisphosphonates were suspended in $16 \%$. In the $3 \%$ of patients sunitinib dose was reduced from $50 \mathrm{mg} /$ day to $37.5 \mathrm{mg} /$ day, and in 3\% hyperbaric oxygen therapy was used.

Analyzing the improvement, it was only evaluated in four cases $(8,14,17,19)$. In the first case, improvement was observed 2 weeks after the interruption of sunitinib, and in another case 3 weeks after the interruption of sunitinib. The third patient improved after 6 weeks after stopping the bisphosphonate, while continuing with sunitinib. In the last case, improvement was observed, although with the presence of ONJ remnants, 5 months after the suspension of sunitinib.

-Risk of bias across studies

In Figure 2, it can be observed that in case reports most of the studies have a low risk of bias. Only in the question "Was the post-intervention clinical condition clearly described?" $15 \%$ corresponded to a high risk of bias, and in the question "Were adverse events (harm) or incapacitated events identified and described?" $30 \%$ had a high risk of bias.

Figure 3 shows the risk of global bias of case series. All the articles have an uncertain risk in the question 
"Did the case series have complete inclusion of participants?". Approximately $50 \%$ of the articles have had an uncertain risk of bias in the questions "Did the case series have consecutive inclusion of participants?", and "Was the statistical analysis appropriate?". In addition, we have considered that $30 \%$ of the studies have a high risk of bias in the question "Were there clear criteria for inclusion in the case series?".

It was not possible to generate a figure for the retrospective studies, because there was only one study with these characteristics. Furthermore, it was not possible perform a meta-analysis due to the quality of the included studies: case series, case reports and only one retrospective study.

\section{Discussion}

-Summary of evidence

The introduction of different antiangiogenic drugs such as sunitinib, in the therapeutic regimen of cancer (22) has caused an increase of ONJ related to other drugs different than bisphosphonates. Most patients receiving sunitinib are related to the treatment of renal cell carcinoma. This type of cancer represents approximately $2 \%$ of all cancers worldwide and its incidence of bone metastases is around $30-35 \%(21,24)$. For this reason, several drugs such bisphosphonates, denosumab or sunitinib are used for their treatment, mainly to prevent bone destruction and tumor growth $(4,9,24)$. It is estimated that $16 \%$ patients with cancer treated with sunitinib, alone or in combination with bisphosphonates, suffer from ONJ (6). For this reason, the European Medicines Agency issued safety warnings about the risk of ONJ during treatment with sunitinib $(6,21)$. Moreover, the AAOMS maintains that ONJ can develop in patients undergoing treatment with antiangiogenic agents such as sunitinib (25). However this association has not been analyzed in depth (20). In this paper, we have analyzed studies that have shown the presence of ONJ in patients treated with sunitinib, alone or combined with bisphosphonates. Most authors agree that the risk of ONJ is greater when antiangiogenic drugs are combined with bisphosphonates $(3,8,14,16,21,23)$, others such as Ashrafi et al. maintain that $\mathrm{ONJ}$ is more related to the use of sunitinib than to bisphosphonates, because the side effects improve with the disruption of sunitinib (14). On the other hand some authors argue that there is not enough evidence in the literature about the cause-effect relationship between sunitinib and ONJ (26).

-ONJ in patients receiving concomitant treatment with sunitinib and bisphosphonates

As we have seen, in this revision 49 from 58 (84\%) patients with ONJ were under concomitant treatment with sunitinib and bisphosphonates. The retrospective study by Beuselinck et al. shows that the incidence of ONJ in patients with renal cell cancer increased up to
$10 \%$ when combined treatment with bisphosphonates and sunitinib were added (21). Some authors justify this higher risk due to the greater cumulative toxicity profile in patients treated with bisphosphonates and sunitinib, since both drugs have an antiangiogenic effect (9). However, it is remarkable that ONJ was only observed in patients treated with zoledronate in combination with sunitinib and not with the combination of zoledronate with sorafenib, pazopanib, temsirolimus or immunotherapy based on IL-2 $(22,25)$. This could be explained because sunitinib is between $10 \%-30 \%$ more potent against VEGFR and PDGF than the other drugs $(8,16,18,21)$. Another reason is that this drug can also cause damage to the oral mucosa producing gingival inflammation and mucositis, delaying wound healing and favoring infection. This in turn would increase the risk of ONJ $(9,14)$. Indeed, some authors describe cases in which oral mucositis preceded bone exposure (4).

-ONJ local risk factors associated with sunitinib It has been suggested that the local risk factors of ONJ associated with sunitinib are similar to those of ONJ associated with bisphosphonates. Among the dental risk factors, it should be noted that tooth extraction is the most frequent triggering event (27). But there are other precipitating local factors such as other types of dentoalveolar surgery, the continued trauma to the mucosa (such as that produced by a removable prosthesis), the presence of exostosis, oral infection, the presence of periodontitis and poor oral hygiene $(4,9,20,25)$. There are authors who also consider tobacco as a risk factor for ONJ (17).

In our work, we have observed how the local risk factors most frequently associated with the onset of ONJ were tooth extraction and dentoalveolar surgery, followed by dental or periodontal infections. Other risk factors were mucositis due to chemotherapy, the use of removable dentures or implant insertion. We found that $14 \%$ of cases were spontaneous.

-ONJ systemic risk factors associated with sunitinib There are also a number of systemic risk factors for ONJ, including the duration of administration of antiresorptive drugs, the dose, the simultaneous use of antiangiogenic and antiresorptive drugs, treatment with chemotherapy or concomitant corticosteroids, or diseases such as diabetes $(16,27)$. Since the introduction of targeted therapies, the life expectancy of patients with metastatic renal cell cancer has tripled, but this also leads to prolonged exposure to treatments such as bisphosphonates and anti-angiogenic drugs that increase the risk of ONJ $(9,21)$. Also chemotherapy can be another systemic risk factor. There are controversies as to whether sunitinib is a conventional chemotherapy treatment or not. Authors such as Hoefert et al. differentiate sunitinib from conventional chemotherapy according to the treatment length. Conventional chemotherapy is given for a defined period of time, but sunitinib can be maintained for 
a longer period of time, sometimes even years, which also increases the risk of ONJ $(4,14)$. There are articles included in this study that show how the time elapsed between the initiation of treatment with sunitinib and the appearance of ONJ varied from 7 to 9 months (4). In comparison with bevacizumab, Mahedi Mohamed et al. suggest that the duration of treatment with sunitinib before the onset of ONJ is longer (20).

All patients included in this study received sunitinib for renal cell carcinoma, with or without metastasis. The patients received this drug orally, and the duration of the treatment ranged from 1 to 36 months. Ninety-one per cent of the patients with ONJ received sunitinib at a dose of $50 \mathrm{mg} /$ day. Of the cases of ONJ, only 5 patients (9\%) received sunitinib without being associated with other medications that cause ONJ. As we have seen 49 patients (84\%) were administered sunitinib in combination with bisphosphonates simultaneously, with zolendronic acid predominating.

-Location of ONJ with sunitinib treatment

In previous studies performed on the ONJ in patients medicated with bisphosphonates it was observed that the lesions occurred mostly in the mandible (68.1\%), and to a lesser extent in the maxilla $(27.7 \%)$ or in both jaws (4.2\%) (27). Regarding the ONJ lesions of this study, $54 \%$ of cases occurred in the mandible and $33 \%$ in the maxilla. So it seems that the location is similar to the case of bisphosphonates.

-Treatment protocol

The established protocol in a case of ONJ associated with sunitinib is very variable and there are discrepancies among the authors. There are authors who propose that administration of systemic antibiotics, exhaustive oral hygiene, the use of rinses with chlorhexidine, together with the temporary interruption of sunitinib can lead to clinical improvement of the oral lesions $(9,14,16,19)$. The healing time of the soft tissues after the interruption of sunitinib seems to be relatively short, in some studies it is estimated between 2-4 weeks $(4,9)$, however when treatment is restarted ONJ relapses again $(4,19)$.

Other authors such as Hoefert et al. (4) suggest that since most of the side effects are reversible, treatment with sunitinib should not be stopped, although dose adjustment has been recommended. Agrillo et al. (15) also are in favor of continuing sunitinib, although recommends bisphosphonate disruption in patients under combining treatment.

If we observe the included studies of this systematic review, the most frequent treatments of ONJ were antibiotic therapy $(26 \%)(4,8,9,14,15,19,22,23)$, chlorhexidine mouthwashes (18\%) $(4,9,14,15,16,22)$, sunitinib (18\%) $(4,8,9,14,15,16,19)$, and bisphosphonates suspension $(16 \%)(15,16,17,23)$, and surgery $(16 \%)(4,15,16,18,22)$. The improvement was only evaluated in four cases $(7,14,15,19)$. In 3 of these cases improvement was ob- served after interruption of sunitinib, but the improvement time was very variable, from 2 weeks to 5 months $(7,14,19)$. Interestingly the fourth patient improved following 6 weeks after stopping the bisphosphonate, while continuing with sunitinib (17).

Prevention is the main objective of disease control (16), however there are no specific guidelines nowadays (4). Some authors such as Nicolatou-Galitis et al. advise using the same recommendations used in patients receiving bisphosphonates (9). The oral examination prior to treatment with sunitinib is aimed at reducing the oral microbial load and infection; this will reduce the degree of oral mucositis induced by chemotherapy, which may reduce the risk of developing MRONJ (9). In a study of patients with renal cell carcinoma and bone metastases treated with zoledronic acid combining with target therapy carried out by McKay et al. (24), the ONJ rate was $29 \%$ and was only observed in patients treated with sunitinib. After the introduction of mandatory oral examinations before the use of these drugs, the rates decreased to $11 \%$ (24). This theoretically justifies the dental check-ups prior to treatment with sunitinib and other antiresorptive drugs. It is also important to perform periodic check-ups during treatment because oral changes, different to $\mathrm{ONJ}$, appear in $10-50 \%$ of patients treated with sunitinib and include dysgeusia, xerostomia, mucosal sensitivity, oral pain, gingival bleeding, gingivitis necrotizing and oral mucositis $(4,9)$.

-Limitations

Regarding the limitations of this systematic review, we could highlight the type and characteristics of most of the included studies, since case series or isolated clinical cases with very low methodological quality predominate. In addition, each author defined different characteristics of their patients, making it difficult to unify the aspects that may influence the development of ONJ. Therefore, no meta-analysis was performed.

For this reason, there is a need to better evaluate the incidence of ONJ in large cohorts of patients prospectively, given the increasing use of treatment with antiresorptive drugs, targeted therapies, antiangiogenic drugs and bisphosphonates in the modern era of oncology.

\section{Conclusions}

With the introduction of sunitinib as a new treatment, a growing number of patients with ONJ have been reported, it is suggested that the antiangiogenic activity of the targeted agents can inhibit bone remodeling, delay the healing of the tissues and thus enhancing the development of ONJ. In addition, the mucositis produced by this drug may also increase the risk of ONJ. Most authors agree on an increased risk of developing ONJ in those cases in which bisphosphonates and sunitinib are combined.

To reduce the incidence of $\mathrm{ONJ}$, a clinical examination 
should be carried out on all patients before and periodically during treatment with these drugs. A correct oral situation and careful oral hygiene play a fundamental role in preventing this pathology.

It is necessary that dentists, oral and maxillofacial surgeons as well as oncologists know this relationship, in order to establish a protocol of periodic oral check-ups to reduce the risk of $\mathrm{ONJ}$ and make an early diagnosis. Knowledge about the relationship between ONJ and new target therapies such as sunitinib is still limited. There are discrepancies in the protocol to be followed in case of ONJ, although it seems that the suspension of the drug improves the situation. For this reason, there is an imperative need to continue researching in this field.

\section{References}

1. Khan AA, Morrison A, Hanley DA, Felsenberg D, McCauley LK, O'Ryan F, et al. Diagnosis and management of osteonecrosis of the jaw: a systematic review and international consensus. J Bone Miner Res. 2015;30:3-23.

2. Bagan J, Peydró A, Calvo J, Leopoldo M, Jiménez Y, Bagan L. Medication-related osteonecrosis of the jaw associated with bisphosphonates and denosumab in osteoporosis. Oral Dis. 2016;22:324-9.

3. Ramírez L, López-Pintor RM, Casa-as E, Arriba L, Hernández G. New Non-Bisphosphonate Drugs that Produce Osteonecrosis of the Jaws. Oral Health Prev Dent. 2015;13:385-93.

4. Hoefert S, Eufinger H. Sunitinib may raise the risk of bisphosphonate-related osteonecrosis of the jaw: presentation of three cases. Oral Surg Oral Med Oral Pathol Oral Radiol Endod. 2010;110:463-9.

5. Goodman VL, Rock EP, Dagher R, Ramchandani RP, Abraham S, Gobburu JV, et al. Approval Summary: Sunitinib for the Treatment of Imatinib Refractory or Intolerant Gastrointestinal Stromal Tumors and Advanced Renal Cell Carcinoma. Clin Cancer Res. 2007; 13:1367-73.

6. Beuselinck B, Wolter P, Karadimou A, Elaidi R, Dumez H, Rogiers A, et al. Concomitant oral tyrosine kinase inhibitors and bisphosphonates in advanced renal cell carcinoma with bone metastases. Br J Cancer. 2012;107:1665-71.

7. Fleissig Y, Regev E, Lehman H. Sunitinib related osteonecrosis of jaw: a case report. Oral Surg Oral Med Oral Pathol Oral Radiol. 2012;113:1-3.

8. Medicines and Healthcare products Regulatory Agency Gov. UK [sede Web]. UK 2011. [acces 20 mayo de 2018]. Bevacizumab and sunitinib: risk of osteonecrosis of the jaw. Drug Safety Update. 2001;4(6):1. Available in: https:/www.gov.uk/drug-safety-update/ bevacizumab-and-sunitinib-risk-of-osteonecrosis-of-the-jaw

9. Nicolatou-Galitis O, Migkou M, Psyrri A, Bamias A, Pectasides $\mathrm{D}$, Economopoulos T, et al. Gingival bleeding and jaw bone necrosis in patients with metastatic renal cell carcinoma receiving sunitinib: report of 2 cases with clinical implications. Oral Surg Oral Med Oral Pathol Oral Radiol. 2012;113:234-8.

10. Moher D LA, Tetzlaff J, Altman DG, . The PRISMA Group (2009). Preferred Reporting Items for Systematic Reviews and MetaAnalyses: The PRISMA Statement. . PLoS Med. 2009;6:e1000097.

11. Ruggiero SL, Dodson TB, Fantasia J, Goodday R, Aghaloo T, Mehrotra B, et al. American Association of Oral and Maxillofacial Surgeons position paper on medication-related osteonecrosis of the jaw--2014 update. J Oral Maxillofac Surg. 2014;72:1938-56.

12. Moola S, Munn Z, Tufanaru C, Aromataris E, Sears K, et al. Chapter 7: Systematic reviews of etiology and risk. In: Aromataris E, Munn Z (Editors). Joanna Briggs Institute Reviewer's Manual. The Joanna Briggs Institute, 2017. Available from https://reviewersmanual.joannabriggs.org/

13. Wells, G. A, Shea, B., O'Connel, D. et al. The Newcastle-Ottawa scale (NOS) for assessing the quality of nonrandomized studies in meta-analyses. http://www ohri ca/programs/clinical epidemiology/ oxford

14. Ashrafi F, Derakhshandeh A, Movahedian B, Moghaddas A. Osteonecrosis of the Jaws in Patient Received Bisphosphonates and Sunitinib Separately: A Case Report. J Res Pharm Pract. 2017;6:1825.

15. Agrillo A, Nastro Siniscalchi E, Facchini A, Filiaci F, Ungari C. Osteonecrosis of the jaws in patients assuming bisphosphonates and sunitinib: two case reports. Eur Rev Med Pharmacol Sci. 2012;16:952-7.

16. Balmor GR, Yarom N, Weitzen R. Drug-induced palate osteonecrosis following nasal surgery. Isr Med Assoc J. 2012;14:193-4.

17. Bozas G, Roy A, Ramasamy V, Maraveyas A. Osteonecrosis of the jaw after a single bisphosphonate infusion in a patient with metastatic renal cancer treated with sunitinib. Onkologie. 2010;33:321-3.

18. Koch FP, Walter C, Hansen T, Jäger E, Wagner W. Osteonecrosis of the jaw related to sunitinib. J Oral Maxillofac Surg. 2011;15:63-6. 19. Brunello A, Saia G, Bedogni A, Scaglione D, Basso U. Worsening of osteonecrosis of the jaw during treatment with sunitinib in a patient with metastatic renal cell carcinoma. Bone. 2009;44:173-5.

20. Mahedi Mohamed AH, Nielsen CE, Schiodt M. Medication related osteonecrosis of the jaws associated with targeted therapy as monotherapy and in combination with antiresorptives. A report of 7 cases from the Copenhagen Cohort. Oral Surg Oral Med Oral Pathol Oral Radiol. 2018;125:157-63.

21. Fusco V, Porta C, Saia G, Paglino C, Bettini G, Scoletta M, et al. Osteonecrosis of the jaw in patients with metastatic renal cell cancer treated with bisphosphonates and targeted agents: Results of an Italian multicenter study and review of the literature. Clin Genitourin Cancer. 2015;13:287-94.

22. Smidt-Hansen T, Folkmar TB, Fode K, Agerbaek M, Donskov F. Combination of zoledronic Acid and targeted therapy is active but may induce osteonecrosis of the jaw in patients with metastatic renal cell carcinoma. J Oral Maxillofac Surg. 2013;71:1532-40.

23. Christodoulou C, Pervena A, Klouvas G, Galani E, Falagas ME, Tsakalos G, et al. Combination of bisphosphonates and antiangiogenic factors induces osteonecrosis of the jaw more frequently than bisphosphonates alone. Oncology. 2009;76:209-1.

24. McKay RR, Lin X, Perkins JJ, Heng DY, Simantov R, Choueiri TK. Prognostic significance of bone metastases and bisphosphonate therapy in patients with renal cell carcinoma. Eur Urol. 2014;66:5029.

25. Ripamonti CI, Lucchesi M, Giusti R. Prevention and management of osteonecrosis of the jaw secondary to bone-targeted therapy in patients with kidney cancer. Curr Opin Support Palliat Care. 2016;10:273-80.

26. Troeltzsch M, Woodlock T, Kriegelstein S, Steiner T, Messlinger K, Troeltzsch M. Physiology and pharmacology of nonbisphosphonate drugs implicated in osteonecrosis of the jaw. J Can Dent Assoc. 2012;78:85.

27. Martins AS, Correia JA, Salvado F, Caldas C, Santos N, Capelo A, et al. Relevant factors for treatment outcome and time to healing in medication related osteonecrosis of the jaws - A retrospective cohort study. J Craniomaxillofac Surg. 2017;45:1736-42.

28. Marx RE, Sawatari Y, Fortin M, Broumand V. Bisphosphonateinduced exposed bone (osteonecrosis/osteopetrosis) of the jaws: risk factors, recognition, prevention, and treatment. J Oral Maxillofac Surg. 2005;63:1567-75.

\section{Funding}

There were no sources of funding for this research.

\section{Conflict of interest}

The authors have declared that no conflicts of interest exist. 